\title{
Dietary Supplements for Health, Adaptation, and Recovery in Athletes
}

\author{
Eric S. Rawson \\ Messiah College \\ Mary P. Miles \\ Montana State University \\ D. Enette Larson-Meyer \\ University of Wyoming
}

\begin{abstract}
Some dietary supplements are recommended to athletes based on data that supports improved exercise performance. Other dietary supplements are not ergogenic per se, but may improve health, adaptation to exercise, or recovery from injury, and so could help athletes to train and/or compete more effectively. In this review, we describe several dietary supplements that may improve health, exercise adaptation, or recovery. Creatine monohydrate may improve recovery from and adaptation to intense training, recovery from periods of injury with extreme inactivity, cognitive processing, and reduce severity of or enhance recovery from mild traumatic brain injury (mTBI). Omega 3-fatty acid supplementation may also reduce severity of or enhance recovery from mTBI. Replenishment of vitamin D insufficiency or deficiency will likely improve some aspects of immune, bone, and muscle health. Probiotic supplementation can reduce the incidence, duration, and severity of upper respiratory tract infection, which may indirectly improve training or competitive performance. Preliminary data show that gelatin and/or collagen may improve connective tissue health. Some anti-inflammatory supplements, such as curcumin or tart cherry juice, may reduce inflammation and possibly delayed onset muscle soreness (DOMS). Beta-hydroxy beta-methylbutyrate (HMB) does not consistently increase strength and/or lean mass or reduce markers of muscle damage, but more research on recovery from injury that includes periods of extreme inactivity is needed. Several dietary supplements, including creatine monohydrate, omega 3 -fatty acids, vitamin D, probiotics, gelatin, and curcumin/tart cherry juice could help athletes train and/or compete more effectively.
\end{abstract}

Keywords: creatine, curcumin, gelatin, HMB, omega 3 fatty acids, probiotics, tart cherry juice, vitamin D

Several dietary supplements, including carbohydrate, caffeine, creatine monohydrate, nitrate, beta-alanine, and sodium bicarbonate, are well-established performance enhancers (see Peeling et al., 2018). Additionally, the beneficial effects of protein on the adaptive response to exercise has been well studied (see Hector \& Phillips, 2018). Further, some supplements, such as caffeine and carbohydrate, may augment both muscle and brain performance (see Peeling et al., 2018). There is also research indicating that some other dietary supplements may be valuable in enhancing muscular adaptations to exercise, improving brain performance, decreasing delayed onset muscle soreness or pain, reducing injury severity, enhancing recovery from injury, reducing gastrointestinal problems, and decreasing respiratory tract infection illness load. For the most part, these effects are not ergogenic, but may help athletes to train and/or compete more effectively without performance impediments. These supplements include creatine monohydrate,

Rawson is with the Department of Health, Nutrition, and Exercise Science, Messiah College, Mechanicsburg, PA. Miles is with the Department of Health and Human Development, Montana State University, Bozeman, MT. Larson-Meyer is with the Nutrition \& Exercise Laboratory, Department of Family and Consumer Sciences, University of Wyoming, Laramie, WY. Address author correspondence to Eric S. Rawson at erawson@messiah.edu. beta-hydroxy beta-methylbutyrate (HMB), omega-3 fatty acids, vitamin $\mathrm{D}$, probiotics, gelatin, and anti-inflammatory supplements such as curcumin or tart cherry juice. The potential benefits of these dietary supplements are summarized in Table 1.

\section{Creatine Monohydrate}

\section{Muscular Adaptations}

The ingestion of the dietary supplement creatine monohydrate (about $20 \mathrm{~g} /$ day for 5 days) increases muscle creatine by about 20\% (Harris et al., 1992; Hultman et al., 1996). Subsequently, the performance of sports and exercises that rely heavily on creatine and phosphorylcreatine to resynthesize adenosine triphosphate (ATP) (e.g., <30 s, intense, repeated bouts) can be improved (reviewed in Branch, 2003; Gualano et al., 2012; Rawson \& Volek, 2003). In addition to the well-established performanceenhancing effects, creatine monohydrate also works through multiple mechanisms to enhance muscle recovery from intense exercise (reviewed in Heaton et al., 2017).

Muscle phosphorylcreatine and glycogen can be depleted following intense exercise, but creatine supplementation can enhance replenishment of these fuel sources. Faster postexercise 
Table 1 Dietary Supplements for Health, Adaptation, and Recovery in Athletes

\begin{tabular}{|c|c|c|c|c|}
\hline Supplement/Nutrient & Deficiency & $\begin{array}{l}\text { Dysfunction } \\
\text { With } \\
\text { Deficiency }\end{array}$ & $\begin{array}{l}\text { Potential Benefits of } \\
\text { Supplementation }\end{array}$ & Comments \\
\hline $\begin{array}{l}\text { Creatine monohydrate: } \\
\text { Creatine is a naturally } \\
\text { occurring nutrient, consumed } \\
\text { in the diet, and synthesized in } \\
\text { the body. Recommended } \\
\text { supplement dose is } 20 \mathrm{~g} / \text { day } \\
\text { for } 5 \text { days followed by } 3 \text { to } \\
5 \text { g/day to increase and } \\
\text { maintain elevated body }\end{array}$ & $\begin{array}{l}\text { Low dietary } \\
\text { creatine intake } \\
\text { (e.g., vegan, } \\
\text { vegetarian, or } \\
\text { low meat eater) } \\
\text { decreases } \\
\text { muscle and } \\
\text { blood muscle } \\
\text { creatine }\end{array}$ & $\begin{array}{l}\text { No adverse } \\
\text { clinical or } \\
\text { performance } \\
\text { findings with } \\
\text { dietary-induced } \\
\text { deficiency. }\end{array}$ & $\begin{array}{l}\text { Increased lean mass/strength; } \\
\text { enhanced recovery from intense } \\
\text { exercise (faster PCr and glycogen } \\
\text { resynthesis); enhanced adaptive } \\
\text { response to exercise via increased } \\
\text { growth factor/gene expression, } \\
\text { increased intracellular water; } \\
\text { reduced symptoms of or enhanced } \\
\text { recovery from muscle damaging }\end{array}$ & $\begin{array}{l}\text { Well studied. Excellent safety profile. } \\
\text { A small increase in body mass is } \\
\text { common with supplementation. This } \\
\text { may be relevant for sports with weight } \\
\text { classes/restrictions or where increased } \\
\text { body mass may decrease performance. } \\
\text { Not known if improved cognitive } \\
\text { processing translates into improved } \\
\text { athletic performance. }\end{array}$ \\
\hline
\end{tabular}

creatine levels (Harris et al., 1992; Hultman et al., 1996).

Beta-hydroxy Betamethylbutyrate (HMB):

HMB is a metabolite of the amino acid leucine.

Manufacturer recommended dosage is $3 \mathrm{~g} /$ day (Rowlands \& Thomson, 2009; SanchezMartinez et al., 2017).

Vitamin D: An essential fat-soluble vitamin. Skin exposure to sunlight accounts for $90 \%$ of the source of vitamin D.

Omega 3-fatty acids: Dose most commonly studied is about $2 \mathrm{~g} /$ day (Jeromson et al., 2015; Mickleborough, 2013).

Probiotics: Effective dosing regimens of $10^{9}$ to $4 \times 10^{10}$ CFU for 4 to 21 weeks in duration (Pyne et al., 2015).

\section{N/A/ N/A}

Insufficiency/ deficiency has been identified in athletes from recreational through professional levels especially, but not exclusively, when access to sunlight is limited

Not described in athletes.

Not described in athletes.

Blunted adapted to response to exercise likely; increased URTI; increased injury, stress fractures. exercise (e.g., DOMS); enhanced recovery from disuse, immobilization, or extreme inactivity such as after injury; improved cognitive processing; decreased risk/ enhanced recovery from mTBI.

Enhanced lean mass, strength, and adaptation to exercise via decreased muscle protein breakdown; reduced symptoms of or enhanced recovery from muscle damaging exercise (e.g., decreased DOMS).

Improved adaptive response to exercise; decreased incidence, duration, and severity of URTI; decreased stress fractures.

Improved cognitive processing; decreased risk/enhanced recovery from mTBI; reduced symptoms of or enhanced recovery from muscle damaging exercise (e.g., DOMS).

N/A N/A

Decreased severity or duration of gastrointestinal problems; decreased incidence, duration, and severity of URTI.
Cannot be confidently recommended to athletes. Effects may be no more effective than adhering to the current protein intake recommendations. May prove useful in rehabilitation where there may be periods of extreme inactivity, but few data are available.

RDA 600 IU/d; identify deficiencies through blood work, consult with a physician and sport nutritionist, and take corrective actions in insufficient/ deficient athletes with changes in lifestyle, food intake, and possibly supplementation; indiscriminate vitamin D supplementation for athletes is not advised; compensatory response to high-dose supplementation possible (e.g., decreased PTH), but not well studied.

Not known if improved cognitive processing translates into improved athletic performance; few data on mTBI, but animal data and two case studies show that the structural damage and cognitive decline associated with mTBI are reduced/attenuated with omega-3 fatty acid; benefits to muscle damage are not a consistent finding; low risk but unclear if supplementation should be pursued by athletes, in lieu of including fatty fish in the diet as a source of omega- 3 fatty acids.

Modest benefits to athletes prone to GIT problems or traveling to regions in which GIT problems are more likely; most studies report reduced incidence, duration, and severity of URTI in athlete; many different probiotic supplements have been studied, so specific recommendations and conclusions are difficult to ascertain; supplementation needs to begin well ahead of competition. 
Table 1 (continued)

\begin{tabular}{|c|c|c|c|c|}
\hline Supplement/Nutrient & Deficiency & $\begin{array}{l}\text { Dysfunction } \\
\text { With } \\
\text { Deficiency }\end{array}$ & $\begin{array}{l}\text { Potential Benefits of } \\
\text { Supplementation }\end{array}$ & Comments \\
\hline $\begin{array}{l}\text { Gelatin and vitamin } \mathrm{C} / \\
\text { collagen: Recommended } \\
\text { dose of gelatin is } 5 \text { to } 15 \mathrm{~g} \\
\text { gelatin w/50 mg vitamin } \mathrm{C} \\
\text { (Shaw et al., 2017). }\end{array}$ & N/A & N/A & $\begin{array}{l}\text { Increased collagen production, } \\
\text { thickened cartilage, decreased } \\
\text { knee pain. }\end{array}$ & $\begin{array}{l}\text { Gelatin and collagen supplements } \\
\text { appear to be low risk; few data are } \\
\text { available; functional benefits, recovery } \\
\text { from injury, and effects in elite athletes } \\
\text { are not known. }\end{array}$ \\
\hline
\end{tabular}

Collagen hydrolysate dose is

about $10 \mathrm{~g} /$ day (Clark et al.,

2008; McAlindon et al.,

2011).

Anti-inflammatory
supplements: Curcumin is a

constituent of the spice

turmeric, and supplements

are often ingested at a dose

of about $5 \mathrm{~g}$ /day (McFarlin

et al., 2016; Nicol et al.,

2015).

Tart cherry juice is ingested at a dose of about 8 to $12 \mathrm{oz}$. ( $1 \mathrm{oz}$. if concentrate) twice/ day for 4 to 5 days before an athletic event or for 2 to

3 days afterwards to promote recovery (Bell et al., 2014, Coelho Rabello Lima et al., 2015).
N/A N/A

Anti-inflammatory effects; reduced symptoms of or enhanced recovery from muscle damaging exercise (e.g., decreased DOMS).
Reduced DOMS may be important in sports where soreness might impair performance in a subsequent bout of exercise; benefits may be sport/training specific; more research needs to be conducted before these compounds could be recommended to athletes.

Abbreviations: $\mathrm{CFU}=$ colony forming units; DOMS = delayed onset muscle soreness; $\mathrm{GIT}=$ gastrointestinal tract; $\mathrm{mTBI}=$ mild traumatic brain injury; $\mathrm{PCr}=$ phosphoryl creatine; $\mathrm{PTH}=$ parathyroid hormone; RDA = recommended dietary allowance; URTI = upper respiratory tract illness.

phosphorylcreatine resynthesis may improve recovery from an acute bout of sprint type exercise, or during repeated bouts of sprints, which mimics the stop and go, intermittent nature of many sports. Consequently, this could improve exercise performance in subsequent bout(s) a few minutes later (Greenhaff et al., 1994; Yquel et al., 2002). Also, simultaneous creatine and carbohydrate loading further increases glycogen resynthesis $(12 \%)$ (Nelson et al., 2001 ), with $82 \%$ of this increase occurring during the first $24 \mathrm{hr}$ (Roberts et al., 2016) (reviewed in Volek \& Rawson, 2004). This could enhance the performance of a subsequent bout of exercise occurring hours or days later.

It is unlikely that creatine improves the adaptive response to exercise through direct effects on muscle protein synthesis (MPS) or muscle protein breakdown (MPB) (Louis, Poortmans, Francaux, Berre et al., 2003; Louis, Poortmans, Francaux, Hultman et al., 2003), although one group found that creatine decreased plasma leucine rate of appearance and leucine oxidation (Parise et al., 2001). However, it appears that creatine could enhance the adaptive response by modulating increased expression of growth factors (e.g., myogenin, MRF-4, insulin-like growth factor I and II [IGF-I and IGF-II]; Burke et al., 2008; Deldicque et al., 2005; Willoughby \& Rosene, 2001, 2003). Further, creatine supplementation plus resistance training increases satellite cell number and myonuclei concentration more than resistance training alone (Olsen et al., 2006). Increasing muscle creatine content through supplementation increases expression of multiple genes associated with adaptive processes, including: osmosensing, cytoskeleton remodeling, GLUT4 translocation, glycogen and protein synthesis, satellite cell proliferation and differentiation, DNA replication and repair, mRNA processing and transcription, and cell survival (Safdar et al., 2008). Some of these effects may be modulated by increased intramuscular water (Deminice et al., 2016), which can inhibit protein breakdown and RNA degradation, and stimulate protein, DNA, and RNA synthesis (Berneis et al., 1999; Häussinger et al., 1993).

Rawson et al. (2017) recently reviewed the effects of creatine monohydrate supplementation on markers of exercise-induced muscle damage and found that of 15 studies, eight reported no effect (positive or negative), while seven showed favorable outcomes following stressful exercise. Beneficial effects were noted in the form of decreased postexercise muscle serum proteins (e.g., creatine kinase $[\mathrm{CK}]$ and lactate dehydrogenase $[\mathrm{LDH}]$ ), improved postexercise recovery of strength/force, attenuated postexercise increase in delayed onset muscle soreness (DOMS) or decrease in range of motion, and decreased postexercise inflammatory markers (e.g., prostaglandin-E2 [PGE2], tumor necrosis factor- $\alpha$ $[$ TNF- $\alpha]$, interferon- $\alpha$ [INF- $\alpha$ ], interleukin-1- $\beta$ [IL1- $\beta]$, c-reactive protein $[\mathrm{CRP}])$. These benefits, which were noted across various resistance and endurance exercise challenges, indicate creatine may play a role in reducing muscle damage and inflammation.

\section{Recovery from Disuse/lmmobilization}

Along with decreases in muscle mass and function, muscle creatine decreases as much as $24 \%$ during periods of extreme inactivity, such as during immobilization (MacDougall, Ward, Sale, \& Sutton, 1977). Consequently, maintaining or increasing muscle creatine with supplementation during periods of inactivity or recovery from injury may prove advantageous. Seven studies of the effects of creatine supplementation during immobilization have been 
published, with some positive findings, including: (a) better maintenance of muscle mass/cross sectional area, strength, and muscle endurance; (b) maintenance of or increase in muscle creatine; (c) maintenance of or increased GLUT4; (d) increased muscle glycogen; and (e) increased growth factor (MRF4) expression (Derave et al., 2003; Fransen et al., 2015; Hespel et al., 2001; Johnston et al., 2009; Op 't Eijnde et al., 2001). These studies are difficult to compare as they had different outcomes, were of different durations (1-10 weeks), investigated different limbs (arm vs. leg), and some were exercise training studies. Although positive effects were not found in every outcome of each study (Backx et al., 2017; Eijnde et al., 2005), it appears that creatine supplements may play a role in recovery from disuse.

\section{Brain}

A small amount of creatine is manufactured and stored in the brain where it is used for ATP production. Brain creatine can be increased with creatine supplementation (about 10\%), and this increase may lead to improvements in cognitive processing (reviewed in Gualano et al., 2016; Rae \& Broer, 2015; Rawson \& Venezia, 2011). Most studies demonstrate an improvement in cognitive processing following creatine supplementation, but these studies are difficult to compare due to differences in supplementation protocols (dose: 2.5 to $20 \mathrm{~g} /$ day; duration: days to weeks), populations (old vs. young; vegan vs. meat-eaters), subject state (e.g., rested vs. sleep deprived), and cognitive processing outcomes (reviewed in Gualano et al., 2016; Rae \& Broer, 2015; Rawson \& Venezia, 2011). Also, attempts to translate "improved cognitive processing" to athletes and athletic performance are few. One group compared the effects of acute ingestion of creatine, caffeine, or placebo on a rugby skill passing test in 10 sleep-deprived professional rugby backs (Cook et al., 2011). Both creatine and caffeine attenuated the decrease in skill performance caused by the sleep deprivation, indicating a potential role for creatine in improving sport performance through the brain.

\section{Concussion (Mild Traumatic Brain Injury)}

Following a mTBI, brain creatine decreases (Vagnozzi et al., 2013) and there is a hypometabolic state. These challenges to energy status could be mitigated through creatine supplementation (Barrett et al., 2014; Dean et al., 2017). Additionally, multiple other changes, including membrane disruption, calcium influx, nerve damage, mitochondrial dysfunction, oxidative stress, and inflammation, that could make the brain vulnerable to further injury, could potentially be offset with creatine supplementation (Barrett et al., 2014; Dean et al., 2017). Animal data indicate that creatine supplementation, prior to traumatic brain injury, can decrease damage up to $50 \%$ (Sullivan et al., 2000). Indirectly, the potential benefits of creatine supplementation on mTBI are supported by the data of Turner et al. (2015), who showed improved cognitive processing in humans during oxygen deprivation, which mirrors some of the effects of mTBI. Data on creatine supplementation and mTBI are limited to two open-label trials in children, but there were improvements in cognition, communication, self-care, personality, and behavior, and decreased headaches, dizziness, and fatigue (Sakellaris et al., 2006, 2008). The potential benefits of creatine supplementation on reducing the severity of or enhancing recovery from mTBI need to be further studied, and although the data are not conclusive, athletes ingesting creatine for muscular benefits may receive benefits to the brain as well.

\section{$\beta$-Hydroxy $\beta$-Methylbutyrate (HMB)}

HMB is ingested in the diet and is a metabolite of leucine. Animal research indicates that HMB can increase body mass in slaughter animals (reviewed in Szczesniak et al., 2015). As a supplement for humans, HMB is marketed as an anticatabolic nutrient that decreases protein breakdown; a dose of about $3 \mathrm{~g} /$ day has been recommended. Potential mechanisms underlying anticatabolic effects include decreased protein breakdown through reduced expression of components of the ubiquitin proteasome pathway, increased protein synthesis through phosphorylation of mammalian target rapamycin (mTOR) substrates and phosphorylation of eukaryotic initiation factor (eIF2), increased cholesterol synthesis, increased growth hormone and IGF I mRNA, increased proliferation and differentiation of satellite cells, and inhibited apoptosis (reviewed in Szczesniak et al., 2015). However, these potential benefits may be just as easily obtained with ingestion of leucine or whey protein, which increase muscle protein synthesis and anabolic signaling (Wilkinson et al., 2013).

If $\mathrm{HMB}$ is anticatabolic, it could improve training adaptations by decreasing muscle damage or protein breakdown. The effects of HMB supplementation on markers of muscle damage and resistance training adaptations in lean mass and strength have been well reviewed (Fitschen, Wilson, Wilson, \& Wilund, 2013; Molfino, Gioia, Rossi Fanelli, \& Muscaritoli, 2013; Zanchi et al., 2011). While early research and a meta-analysis concluded that HMB supplementation both increased lean mass and decreased muscle damage (Nissen \& Sharp, 2003; Nissen et al., 1996), these conclusions have not stood the test of time. In two meta-analyses, it was concluded that HMB supplementation had inconsequential or trivial effects on strength and fat free mass, especially in trained competitive athletes, and that effects on muscle damage (based on blood creatine kinase levels) were unclear (Rowlands \& Thomson, 2009; Sanchez-Martinez et al., 2017). Unfortunately, data on HMB supplementation are discrepant and difficult to interpret due to clustering of data sources (i.e., positive studies from the same/ similar labs) and reliance on nonspecific markers of muscle damage (e.g., creatine kinase) (Decombaz et al., 2003). Additionally, in some instances, potential conflicts of interest were not fully disclosed (Editor, 2003).

The recent publication of several studies on HMB-free acid (HMB-FA) supplementation where implausible anabolic druglike gains in strength, power, and fat free mass, and reductions in muscle damage were reported (Lowery et al., 2016; Wilson et al., 2013; Wilson et al., 2014) has further complicated interpretation of the HMB literature. These findings have been challenged by other researchers (Gentles \& Phillips, 2017; Phillips et al., 2017), but, at this time, the authors have not responded. HMB appears to have some biologic activity in humans that may aid in muscular adaptations from exercise, but it is doubtful that effects are as powerful as some studies have shown. Perhaps, HMB (reviewed in $\mathrm{Wu}$ et al., 2015), like creatine monohydrate (reviewed in Gualano et al., 2012; Gualano et al., 2016), is of benefit for patient populations or sarcopenic older adults. Unlike creatine monohydrate, HMB cannot be confidently recommended to athletes, as the effects may not be more effective than adhering to the current protein intake recommendations. HMB may prove useful in rehabilitation where there may be periods of extreme inactivity, as Deutz and others (2013) showed better preservation of lean mass in older adults ingesting HMB during 10 days of bed rest. 


\section{Omega-3 Fatty Acids}

Omega-3 polyunsaturated fatty acids are essential fatty acids that are consumed in the diet and concentrated in foods such as cold-water fatty fish and fish oils. Fish oil and, in particular, eicosapentaenoic acid (EPA) and docosahexaenoic acid (DHA), supplements have been studied for their effects on brain and cardiovascular health, muscular performance, and recovery from injury (reviewed in Barrett et al., 2014; Erdman et al., 2011; Jeromson et al., 2015; Mickleborough, 2013; Tipton, 2015). EPA and DHA are important cell membrane components in brain and muscle, and it is possible that altering the lipid content of the membrane through dietary consumption of omega- 3 fatty acids can alter membrane function. Cognitive improvements following DHA/EPA supplementation have been noted in several studies with populations ranging from healthy older adults, to those with mild cognitive impairment, to Alzheimer's patients (reviewed in Barrett et al., 2014). It is not known if omega-3 fatty acid supplementation would improve cognitive processing in elite athletes, or how/if this would translate into improved athletic performance. Results from animal studies strongly suggest that omega-3 fatty acid supplementation before or after mTBI reduces structural damage and subsequently attenuates the expected decline in cognitive function (reviewed in Barrett et al., 2014; Erdman et al., 2011; Tipton, 2015). With the exception of two case studies, which showed improvements from supplementation (Lewis et al., 2013; Roberts et al., 2016), it is not known how these data translate to humans, but large, double-blind, placebocontrolled trials are currently underway (clinicaltrials.gov NCT101903525, NCT01814527).

Omega-3 fatty acid supplementation can increase MPS in response to hyperaminoacidemia or hyperinsulinemia (Smith et al., 2011a, 2011b), although this increase may not occur in the presence of recommended postexercise protein intake (30 g) (McGlory et al., 2016). Recently, Gravina et al. (2017) showed improved performance on the YO-YO test of anaerobic endurance, but no increase in strength, speed, or power in soccer players following 4 weeks of omega-3 fatty acid consumption, indicating minimal functional benefits. Omega-3 fatty acids have anti-inflammatory properties and so could play a role in recovery from intense exercise, particularly if there is a large eccentric component. This concept is supported by studies where eccentric-exercise-induced DOMS was reduced following supplementation (Jouris et al., 2011), but this has not been shown in every case (Gray et al., 2014).

Concerns of fish oil or omega-3 fatty acid consumption would include heavy metal contaminants, bleeding, digestive problems, and increased low density lipoprotein (reviewed in Erdman et al., 2011; Mickleborough, 2013). Additionally, since there are not sufficient data to indicate that decreased dietary or body levels of omega-3 fatty acids cause functional impairments, it is unclear if supplementation should be pursued by athletes, instead of including fatty fish in the diet as a source of omega- 3 fatty acids.

\section{Vitamin D}

Although vitamin D is most associated with bone health, the presence of vitamin D receptors throughout the body, including in skeletal muscle, indicate a role in other tissues. The recommended daily allowance (RDA) for vitamin D in the United States and Canada is $600 \mathrm{IU} /$ day, but vitamin D is also synthesized endogenously. In fact, required amounts of vitamin $\mathrm{D}$ can be obtained entirely from synthesis in the skin via exposure to the ultraviolet B (UVB) rays in sunlight (Hossein-nezhad \& Holick, 2013). Synthesis of vitamin D in skin cells, however, is dependent on factors including time of day of exposure, season, latitude, cloud cover, smog, skin pigmentation, skin area exposed, sunscreen coverage, and age. Cutaneous vitamin $\mathrm{D}$ is not synthesized during the winter at latitudes greater than $\sim 33^{\circ}$ north or south because insufficient UVB photons reach the earth's surface during these months (Hossein-nezhad \& Holick, 2013).

Although there is disagreement over appropriate cut points of serum concentrations of 25-hydroxyvitamin D (the marker of vitamin D status), commonly used cut points define deficient as a serum 25 hydroxyvitamin $\mathrm{D}$ of $<50 \mathrm{nmol} / \mathrm{L}$, insufficient as $<75 \mathrm{nmol} / \mathrm{L}$, sufficient as $>75 \mathrm{nmol} / \mathrm{L}$, and optimal as 100 to $250 \mathrm{nmol} / \mathrm{L}$ (Larson-Meyer, 2015). Using these or similar cut points, it appears that many athletes are insufficient or deficient at various times of the year (Halliday et al., 2011; Larson-Meyer, 2015), including those who live in sunny environments close to the equator (Hamilton et al., 2010). Some data on elite and professional athletes also show a high percentage of deficiency and insufficiency (Allison, Close et al., 2015; Allison, Farooq et al., 2015; Close, Leckey et al., 2013; Close, Russell et al., 2013; Fishman et al., 2016; Maroon et al., 2015; Morton et al., 2012; Owens et al., 2017).

The data on the effects of vitamin $\mathrm{D}$ supplementation on muscle function have been described as equivocal, with discrepancies in research in part caused by differences in baseline 25-hydroxyvitamin D concentrations prior to supplementation (Close et al., 2016). For example, Close, Russell, et al. (2013) showed improved sprint time and vertical jump height following vitamin D supplementation in deficient athletes, but a separate study showed no effect of supplementation on strength (Owens et al., 2014). Owens and colleagues (2015) recently demonstrated that vitamin D supplementation (6 weeks; 4,000 IU/day) improved recovery of posteccentric exercise peak torque in vitamin $D$ insufficient men and increased in vitro myotube hypertrophy. These data strongly suggest a role for adequate vitamin $\mathrm{D}$ in the adaptive process to intense exercise. Whether vitamin D supplementation is necessary for adequate adaptive effects likely depends on the athletes' vitamin D status at the initiation of supplementation.

In addition to muscle function, vitamin D supplementation may also be important for reducing risk of upper respiratory tract infections and stress fractures. These factors compromise an athlete's ability to train and compete. Studies in athletes (Cox et al., 2008; He, Aw Yong, Walsh, \& Gleeson, 2016), military personnel (Laaksi et al., 2007), and the general population (Berry et al., 2011; Ginde et al., 2009; Sabetta et al., 2010) have reported negative associations between vitamin $\mathrm{D}$ status and incidences of upper respiratory tract illness (URTI). One study in college athletes found that serum $25(\mathrm{OH}) \mathrm{D}$ concentrations over the winter and spring were negatively associated with documented frequency of acute URTI (Halliday et al., 2011). The breakpoint for contracting a single episode occurred at $\sim 95 \mathrm{nmol} / \mathrm{l}$ such that all athletes with concentrations lower than this breakpoint experienced one or more episodes of illness, whereas those with higher concentrations had one or fewer episodes. A similar study in endurance athletes reported that a greater proportion of athletes who maintained serum $25(\mathrm{OH}) \mathrm{D}$ concentrations of $<30 \mathrm{nmol} / \mathrm{L}$ presented with URTI symptoms over this time point. The fewest symptoms were reported in those with $25(\mathrm{OH}) \mathrm{D}$ concentrations $>120 \mathrm{nmol} / \mathrm{L}(\mathrm{He}$, Handzlik, et al., 2013). Athletes with low vitamin D concentrations also experienced a higher number of days with upper respiratory symptoms and higher symptom-severity scores. Although additional studies are needed to confirm the effectiveness of 
correcting low vitamin D concentrations through supplementation, a recent randomized, placebo-controlled study in university athletes found that 14-weeks of supplementation with 5,000 IU per day of vitamin D3 during winter training significantly increased salivary secretion rates of immune factors, namely cathelicidin and secretory immunoglobulin A (He, Fraser, et al., 2016). Concerning stress fractures, a study in Finnish military recruits found that stress fracture risk was 3.6 times higher in those with low vitamin D status (serum 25[OH]D concentrations $<12 \mathrm{nmol} / \mathrm{L}$ ) (Ruohola et al., 2006). Further, a randomized, double-blind trial in US female naval recruits found that supplementation (800 IU of vitamin D3 plus 2,000 $\mathrm{mg}$ calcium/day) reduced stress fracture incidence by 20\% (Lappe et al., 2008). Again, while additional studies are needed, vitamin D supplementation may have an impact on reducing stress fracture risk.

Based on the number of deficient athletes, it seems that supplementation is warranted in many athletes. Ideally, the supplemental dose should be dependent on current status, but some experts recommend upwards of 2,000 IU of vitamin D3/day (Holick et al., 2011). Owens and colleagues (2017) reported that elite athletes given high doses of vitamin D (12 weeks; 35,000 or $70,000 \mathrm{IU} /$ week) increased serum 25-hydroxyvitamin D, but also decreased parathyroid hormone $(\mathrm{PTH})$, indicating compensatory changes. Thus, it is prudent to first identify deficiencies through blood work (see Larson-Meyer et al., 2018), then consult with a physician and/or sport nutritionist, and finally take corrective actions in insufficient/deficient athletes with changes in lifestyle and supplementation as needed. More research on the consequences of high-dose, longer-term vitamin D supplementation is encouraged, but indiscriminate high-dose vitamin D supplementation for athletes is not advised.

\section{Probiotics}

Microbes in the gut influence gastrointestinal tract (GIT) functions, the immune system, and metabolite production in a variety of ways that exert influence on exercise. The GIT microbiome primarily consists of a diverse array of bacterial species, each of which interacts with the host in a unique way. This influence ranges from beneficial, to neutral, to pathogenic or opportunistic, and the net effect of the GIT microbiome is a function of the combined effects of many different strains and their relative abundance. By definition, probiotics are strains of bacteria that can maintain viability in supplement form for oral ingestion, survive the acidic gastric environment, adhere and colonize in the GIT, antagonize pathogenic bacteria, and provide health benefit(s) to the host (athlete) (West et al., 2009). There are dozens of bacterial strains used as probiotics, particularly those that produce lactic acid, but each strain is unique with respect to how it responds to and affects the GIT milieu, the GIT, the immune system components within the GIT, and all downstream systems of the body. Thus, it is important to be specific about effects of each specific probiotic strain or combination of strains and not to generalize effects of one probiotic to all probiotics. Research regarding athletes has been undertaken to evaluate the efficacy of probiotic supplementation to (a) prevent or relieve GIT problems during exercise, (b) reduce the impact of URTIs, and (c) improve endurance performance.

While there is a variety of bacteria that have been used as probiotics in clinical studies in athletes, there is more consistency in the dosage and duration generally needed to produce benefits. A single bacterium is a colony-forming unit (CFU) and dosages are expressed using this common terminology. Dosing regimens typically fall within the range of $10^{9}$ to $4 \times 10^{10} \mathrm{CFU}$ for 4 to 21 weeks in duration (Pyne et al., 2015). The convention for naming bacteria is Species strain (e.g., Lactobacillus rhamnosus [L. rhamnosus]). A variety of strains within the Lactobacillus, Bifidobacterium, and, less frequently, the Streptococcus species are used as probiotics. These bacteria are Gram-positive (do not contain endotoxin).

Strenuous and prolonged exercise place stresses on the GIT that increase the likelihood of discomfort, abdominal cramping, acid reflux (heartburn), nausea, vomiting, diarrhea, and leakiness of the gut that may allow endotoxemia to occur (de Oliveira et al., 2014). Splanchnic hypoperfusion leading to ischemia in the gut is accepted as a principle cause, with additional contributions from nutritional, mechanical (e.g., jarring), and genetic influences that make some individuals more susceptible than others (de Oliveira et al., 2014). Probiotic support to increase resilience of the GIT against ischemia is of interest to athletes, particularly for those in prolonged endurance events that have the greatest occurrence of GIT problems that impair or stop performance. The proposed mechanism by which probiotics prevent GIT problems stemming from ischemia are related to improvement in the mucosal and epithelial barriers preventing a 'leaky gut' and in production of anti-inflammatory mediators. Probiotics do not eliminate hypoperfusion of the GIT, thus moderate reduction in severity and duration of gastrointestinal symptoms and exercise-induced endotoxemia are the best outcomes that might be expected in clinical trials. To this end, a number of clinical trials have measured small to moderate decreases in severity or duration of gastrointestinal problems attributed to use of L. rhamnosus, L. fermentum, and two different multi-strain probiotics (Haywood et al., 2014; Kekkonen et al., 2007; Shing et al., 2014; West et al., 2011). However, in the L. fermentum trial, benefits were lower in female participants, and the decrease in severity was accompanied by a two-fold greater increase in the number of and duration of lesssevere symptoms in male participants for the probiotic compared to placebo group. The latter was proposed to be part of the adaptive response to probiotic colonization. Using a biomarker of gut permeability, a supporting clinical trial demonstrated that multistrain probiotic reduced leakiness of the GIT as an underlying cause of GIT distress (Lamprecht et al., 2012). Upon reviewing the evidence, Pyne et al. (2015) reached the reasonable conclusion that athletes prone to GIT problems, or traveling to regions in which GIT problems are more likely, may benefit modestly from the above probiotics, but supplementation needs to begin well ahead of competitions and more research is needed before probiotics are recommended with confidence.

Modulation of the immune system to increase defenses against URTIs is the potential benefit of probiotics for athletes that has been most extensively researched. As a major gateway for pathogen entry, the GIT is heavily protected by the immune system. Two-way communication between the immune system and the GIT microbiome impacts immune defenses throughout the body. Probiotics have been shown to enhance innate immunity (first line of defense) by upregulating immunoglobulins, antimicrobial proteins, phagocytic activity, and natural killer cell activity, and also to enhance acquired immunity by improving antigen presentation and function of $\mathrm{T}$ and $\mathrm{B}$ lymphocytes to neutralize pathogens and virally-infected cells (Bermon et al., 2015; Pyne et al., 2015). This is of particular importance to athletes because exercise may increase susceptibility to URTI by decreasing sIgA, decreasing cell-mediated immunity by decreasing type $1 \mathrm{~T}$ lymphs to make recurrent infections more likely, and glucocorticoid suppression of 
monocyte/macrophage antigen presentation and $\mathrm{T}$ lymphocytes (Lancaster et al., 2004; Martin et al., 2009).

The majority of placebo-controlled clinical trials assessing the efficacy of probiotics for reducing incidence, duration, and severity of URTI in athletes report beneficial outcomes, however, many different probiotics have been used and the differences in trial protocols and outcome measures complicates the drawing of more specific conclusions. Pyne et al. (2015) have provided an excellent summary of 15 clinical trials through 2014 in which 10 of 13 studies reported favorable changes in immune and inflammatory markers, and six of seven studies reporting clinical outcomes for URTI report decreased incidence, duration, and or severity with probiotic supplementation. Trials published more recently follow a similar pattern with decreased ( $\sim$ half) incidence, duration ( $\sim 2$ days shorter), and severity (fewer symptoms) of URTI (Michalickova et al., 2016; Strasser et al., 2016). An additional trial was unable to distinguish placebo and probiotic treatments because of unexpectedly low incidence of URTI in both groups (Gleeson et al., 2016). The different probiotic formulations used across these studies are too numerous to list, so for the sake of brevity, we conclude here that there are many probiotics that may decrease the negative impact on training or competition caused by URTI.

More research is needed to establish whether probiotics improve performance. There is some evidence that lowering GIT permeability may have contributed to a longer time to fatigue while exercising in the heat (Shing et al., 2014). The only other study to evaluate performance found no improvement in a short-duration, high-intensity exercise bout without heat stress with probiotic compared to placebo treatment (Cox et al., 2008).

\section{Gelatin and Collagen}

Much of the research on nutrition and the adaptive response to exercise focuses on dietary supplements that affect skeletal muscle tissue, MPS, and MPB. However, nutritional interventions that could benefit connective tissue proteins would valuable as well (reviewed in Baar, 2017). Shaw et al. (2017) showed the combination of exercise plus a gelatin/vitamin $\mathrm{C}$ supplement $(15 \mathrm{~g}$ gelatin plus $50 \mathrm{mg}$ vitamin $\mathrm{C}$ ) increased collagen production in vitro, and amino terminal propeptide (PINP) in the blood. Collagen hydrolysate supplementation (about $10 \mathrm{~g} /$ day) has been shown to thicken cartilage in osteoarthritis patients (McAlindon et al., 2011), and decrease knee pain in athletes (Clark et al., 2008). These studies suggest a benefit of gelatin plus vitamin $\mathrm{C}$ and/or collagen supplementation, but data on functional benefits in elite athletes, such as performance changes or recovery from injury, are not available.

\section{Anti-Inflammatory Supplements}

A constituent of the spice turmeric, curcumin supplements are often ingested for anti-inflammatory effects at a dose of about $5 \mathrm{~g} /$ day. Potentially, these supplements could be used to decrease muscle damage or DOMS in athletes. Some groups have noted reductions in DOMS, CK, and inflammatory cytokines (e.g., TNF- $\alpha$, IL-8) following eccentric contraction induced muscle damage (McFarlin et al., 2016; Nicol et al., 2015). However, similar protective effects of curcumin and reductions in inflammatory makers (e.g., no effect on IL-6, IL-1, IL-10, or CRP) were not seen following endurance exercise (Sciberras et al., 2015). Tart cherry juice has been shown to decrease muscle damage and inflammatory markers following resistance, high-force eccentric, running, and cycling exercise (reviewed in Bell et al., 2014; Coelho Rabello Lima et al., 2015). There are concerns that blunting inflammation may impair the adaptive response to exercise training. However, at times, such as when there are multiple competitions in a brief period of time, faster recovery of strength or decreased soreness may be more valued by the athlete than adaptation (Bell et al., 2014). Thus, it appears that curcumin and tart cherry juice may offer some benefits to athletes, although these benefits may be sport/training specific, and more research needs to be conducted before they could be recommended to athletes.

\section{Summary}

In this review, several dietary supplements are described that can potentially play a role in health, exercise adaptation, and/or recovery for athletes. As summarized in Table 1, creatine monohydrate, vitamin $\mathrm{D}$, omega 3-fatty acids, probiotics, gelatin/collagen, and certain anti-inflammatory supplements can influence cellular and tissue health, resilience, and repair in ways that may help athletes maintain health, adapt to exercise, and increase the quality and quantity of their training. Creatine monohydrate could be recommended for promoting recovery from, and muscular adaptations to, intense training; recovery from periods of injury that result in extreme inactivity; cognitive processing; and reducing severity of or enhancing recovery from mTBI. Vitamin D insufficiency or deficiency appears common, and the benefits of replenishment with supplementation likely improve some aspects of muscle function. However, athletes should seek a blood test and guidance from a physician to confirm inadequate vitamin D status, and then guidance from a nutrition professional regarding supplementation. There are several potential benefits of Omega fat supplementation on skeletal muscle, but more research needs to be conducted. Like creatine monohydrate, omega 3-fatty acid may reduce severity of or enhance recovery from mTBI. At this time, a recommendation for fatty fish consumption, which would include increased intake of omega 3-fatty acids, protein, vitamins, and minerals, may be more appropriate for athletes than a recommendation for fish oil supplementation. The majority of placebo-controlled clinical trials show that probiotic supplementation can reduce the incidence, duration, and severity of URTI in athletes. It is difficult to make more specific recommendations, as many different probiotic supplements were used in these studies. However, it is likely that there are several probiotic supplements that can improve training or competitive performance by decreasing the negative effects caused by URTI and/or GIT problems. A small amount of literature exists that demonstrates a benefit of gelatin and/or collagen on connective tissue health. As adverse effects from gelatin/collagen supplements appear low, at worst, these supplements are just an inexpensive source of amino acids, so the benefits of supplementation outweigh the risks. Anti-inflammatory supplements, such as curcumin and tart cherry juice, show promise in their ability to reduce markers of muscle damage and/or inflammation. However, it is unknown if these effects can enhance recovery in elite athletes or affect subsequent performance. HMB cannot be recommended at this time, but more research on recovery of muscle injury during periods of extreme inactivity is needed.

\section{Acknowledgments}

Manuscript preparation and editing was undertaken by ESR, MPM, and DELM. All authors approved the final version of the paper. 


\section{References}

Allison, R.J., Close, G.L., Farooq, A., Riding, N.R., Salah, O., Hamilton, B., \& Wilson, M.G. (2015). Severely vitamin D-deficient athletes present smaller hearts than sufficient athletes. European Journal of Preventive Cardiology, 22(4), 535-542. PubMed doi:10.1177/ 2047487313518473

Allison, R.J., Farooq, A., Hamilton, B., Close, G.L., \& Wilson, M.G. (2015). No association between vitamin D deficiency and markers of bone health in athletes. Medicine \& Science in Sports \& Exercise, 47(4), 782-788. doi:10.1249/MSS.0000000000000457

Baar, K. (2017). Minimizing injury and maximizing return to play: Lessons from engineered ligaments. Sports Medicine, 47(Suppl 1), 5-11. PubMed doi:10.1007/s40279-017-0719-x

Backx, E.M., Hangelbroek, R., Snijders, T., Verscheijden, M.L., Verdijk, L.B., de Groot, L.C., \& van Loon, L.J. (2017). Creatine loading does not preserve muscle mass or strength during leg immobilization in healthy, young males: A randomized controlled trial. Sports Medicine, 47(8), 1661-1671. PubMed doi:10.1007/s40279-016-0670-2

Barrett, E.C., McBurney, M.I., \& Ciappio, E.D. (2014). Omega-3 fatty acid supplementation as a potential therapeutic aid for the recovery from mild traumatic brain injury/concussion. Advances in Nutrition, 5(3), 268-277. doi:10.3945/an.113.005280

Bell, P.G., McHugh, M.P., Stevenson, E., \& Howatson, G. (2014). The role of cherries in exercise and health. Scandinavian Journal of Medicine \& Science in Sports, 24(3), 477-490. PubMed doi:10. 1111/sms. 12085

Bermon, S., Petriz, B., Kajeniene, A., Prestes, J., Castell, L., \& Franco, O.L. (2015). The microbiota: An exercise immunology perspective. Exercise Immunology Review, 21, 70-79. PubMed

Berneis, K., Ninnis, R., Häussinger, D., \& Keller, U. (1999). Effects of hyper- and hypoosmolality on whole body protein and glucose kinetics in humans. American Journal of Physiology, 276(1 Pt 1), E188-E195. PubMed

Berry, D.J., Hesketh, K., Power, C., \& Hypponen, E. (2011). Vitamin D status has a linear association with seasonal infections and lung function in British adults. British Journal of Nutrition, 106(9), 1433-1440. PubMed doi:10.1017/S0007114511001991

Branch, J.D. (2003). Effect of creatine supplementation on body composition and performance: a meta-analysis. International Journal of Sport Nutrition and Exercise Metabolism, 13(2), 198-226. doi:10. 1123/ijsnem.13.2.198

Burke, D.G., Candow, D.G., Chilibeck, P.D., MacNeil, L.G., Roy, B.D., Tarnopolsky, M.A., \& Ziegenfuss, T. (2008). Effect of creatine supplementation and resistance-exercise training on muscle insulinlike growth factor in young adults. International Journal of Sport Nutrition and Exercise Metabolism, 18(4), 389-398. PubMed doi:10. 1123/ijsnem.18.4.389

Clark, K.L., Sebastianelli, W., Flechsenhar, K.R., Aukermann, D.F., Meza, F., Millard, R.L., . . . Albert, A. (2008). 24-Week study on the use of collagen hydrolysate as a dietary supplement in athletes with activity-related joint pain. Current Medical Research and Opinion, 24(5), 1485-1496. PubMed doi:10.1185/030079908X 291967

Close, G.L., Hamilton, D.L., Philp, A., Burke, L.M., \& Morton, J.P. (2016). New strategies in sport nutrition to increase exercise performance. Free Radical Biology and Medicine, 98, 144-158. PubMed doi:10.1016/j.freeradbiomed.2016.01.016

Close, G.L., Leckey, J., Patterson, M., Bradley, W., Owens, D.J., Fraser, W.D., \& Morton, J.P. (2013). The effects of vitamin D(3) supplementation on serum total $25[\mathrm{OH}] \mathrm{D}$ concentration and physical performance: A randomised dose-response study. British Journal of Sports Medicine, 47(11), 692-696. PubMed doi:10.1136/bjsports2012-091735

Close, G.L., Russell, J., Cobley, J.N., Owens, D.J., Wilson, G., Gregson, W., . . Morton, J.P. (2013). Assessment of vitamin D concentration in non-supplemented professional athletes and healthy adults during the winter months in the UK: Implications for skeletal muscle function. Journal of Sports Sciences, 31(4), 344-353. PubMed doi:10.1080/02640414.2012.733822

Coelho Rabello Lima, L., Oliveira Assumpcao, C., Prestes, J., \& Sergio Denadai, B. (2015). Consumption of cherries as a strategy to attenuate exercise-induced muscle damage and inflammation in humans. Nutricion Hospitalaria, 32(5), 1885-1893. PubMed doi:10.3305/ nh.2015.32.5.9709

Cook, C.J., Crewther, B.T., Kilduff, L.P., Drawer, S., \& Gaviglio, C.M. (2011). Skill execution and sleep deprivation: Effects of acute caffeine or creatine supplementation - a randomized placebocontrolled trial. Journal of the International Society of Sports Nutrition, 8, 2. doi:10.1186/1550-2783-8-2

Cox, A.J., Gleeson, M., Pyne, D.B., Callister, R., Hopkins, W.G., \& Fricker, P.A. (2008). Clinical and laboratory evaluation of upper respiratory symptoms in elite athletes. Clinical Journal of Sport Medicine, 18(5), 438-445. doi:10.1097/JSM.0b013e318181e501

Dean, P.J.A., Arikan, G., Opitz, B., \& Sterr, A. (2017). Potential for use of creatine supplementation following mild traumatic brain injury. Concussion, 2(2), CNC34. doi:10.2217/cnc-2016-0016

Decombaz, J., Bury, A., \& Hager, C. (2003). HMB meta-analysis and the clustering of data sources. J Appl Physiol (1985), 95(5), 2180-2182; author reply 2182. doi:10.1152/japplphysiol.00563.2003

Deldicque, L., Louis, M., Theisen, D., Nielens, H., Dehoux, M., Thissen, J.P., . . . Francaux, M. (2005). Increased IGF mRNA in human skeletal muscle after creatine supplementation. Medicine \& Science in Sports \& Exercise, 37(5), 731-736. PubMed doi:10.1249/01.MSS. 0000162690.39830 .27

Deminice, R., Rosa, F.T., Pfrimer, K., Ferrioli, E., Jordao, A.A., \& Freitas, E. (2016). Creatine supplementation increases total body water in soccer players: A deuterium oxide dilution study. International Journal of Sports Medicine, 37(2), 149-153. PubMed

de Oliveira, E.P., Burini, R.C., \& Jeukendrup, A. (2014). Gastrointestinal complaints during exercise: Prevalence, etiology, and nutritional recommendations. Sports Medicine, 44(Suppl 1), 79-85. doi:10. 1007/s40279-014-0153-2

Derave, W., Eijnde, B.O., Verbessem, P., Ramaekers, M., Van Leemputte, M., Richter, E.A., \& Hespel, P. (2003). Combined creatine and protein supplementation in conjunction with resistance training promotes muscle GLUT-4 content and glucose tolerance in humans. J Appl Physiol (1985), 94(5), 1910-1916. doi:10.1152/japplphysiol. 00977.2002

Deutz, N.E., Pereira, S.L., Hays, N.P., Oliver, J.S., Edens, N.K., Evans, C.M., \& Wolfe, R.R. (2013). Effect of beta-hydroxy-betamethylbutyrate (HMB) on lean body mass during 10 days of bed rest in older adults. Clinical Nutrition, 32(5), 704-712. doi:10.1016/j.clnu. 2013.02.011

Editor. (2003). Corrigenda. Journal of Applied Physiology, 94(4), 651.

Eijnde, B.O., Derave, W., Wojtaszewski, J.F., Richter, E.A., \& Hespel, P. (2005). AMP kinase expression and activity in human skeletal muscle: Effects of immobilization, retraining, and creatine supplementation. J Appl Physiol (1985), 98(4), 1228-1233. doi:10.1152/ japplphysiol.00665.2004

Erdman, J., Oria, M., \& Pillsbury, L. (2011). Nutrition and Traumatic Brain Injury: Improving Acute and Subacute Health outcomes in Military Personnel. Washington, DC: National Academies Press. 
Fishman, M.P., Lombardo, S.J., \& Kharrazi, F.D. (2016). Vitamin D deficiency among professional basketball players. Orthop J Sports Med, 4(7), 232596711665574. PubMed doi:10.1177/2325967116655742

Fitschen, P.J., Wilson, G.J., Wilson, J.M., \& Wilund, K.R. (2013). Efficacy of beta-hydroxy-beta-methylbutyrate supplementation in elderly and clinical populations. Nutrition, 29(1), 29-36.

Fransen, J.C., Zuhl, M., Kerksick, C.M., Cole, N., Altobelli, S., Kuethe, D.O., \& Schneider, S. (2015). Impact of creatine on muscle performance and phosphagen stores after immobilization. European Journal of Applied Physiology, 115(9), 1877-1886. doi:10.1007/ s00421-015-3172-2

Gentles, J.A., \& Phillips, S.M. (2017). Discrepancies in publications related to HMB-FA and ATP supplementation. Nutrition \& Metabolism, 14, 42. PubMed doi:10.1186/s12986-017-0201-7

Ginde, A.A., Mansbach, J.M., \& Camargo, C.A., Jr. (2009). Association between serum 25-hydroxyvitamin D level and upper respiratory tract infection in the Third National Health and Nutrition Examination Survey. Archives of Internal Medicine, 169(4), 384-390. PubMed doi:10.1001/archinternmed.2008.560

Gleeson, M., Bishop, N.C., \& Struszczak, L. (2016). Effects of Lactobacillus casei Shirota ingestion on common cold infection and herpes virus antibodies in endurance athletes: A placebo-controlled, randomized trial. European Journal of Applied Physiology, 116(8), 1555-1563. PubMed doi:10.1007/s00421-016-3415-x

Gravina, L., Brown, F.F., Alexander, L., Dick, J., Bell, G., Witard, O.C., \& Galloway, S.D. (2017). n-3 fatty acid supplementation during 4 weeks of training leads to improved anaerobic endurance capacity, but not maximal strength, speed, or power in soccer players. International Journal of Sport Nutrition and Exercise Metabolism, 27(4), 305-313. PubMed doi:10.1123/ijsnem.2016-0325

Gray, P., Chappell, A., Jenkinson, A.M., Thies, F., \& Gray, S.R. (2014). Fish oil supplementation reduces markers of oxidative stress but not muscle soreness after eccentric exercise. International Journal of Sport Nutrition and Exercise Metabolism, 24(2), 206-214. PubMed doi:10.1123/ijsnem.2013-0081

Greenhaff, P.L., Bodin, K., Söderlund, K., \& Hultman, E. (1994). Effect of oral creatine supplementation on skeletal muscle phosphocreatine resynthesis. American Journal of Physiology, 266(5 Pt 1), E725-E730. PubMed

Gualano, B., Rawson, E.S., Candow, D.G., \& Chilibeck, P.D. (2016). Creatine supplementation in the aging population: Effects on skeletal muscle, bone and brain. Amino Acids, 48(8), 1793-1805. PubMed doi:10.1007/s00726-016-2239-7

Gualano, B., Roschel, H., Lancha-Jr, A.H., Brightbill, C.E., \& Rawson, E.S. (2012). In sickness and in health: The widespread application of creatine supplementation. Amino Acids, 43(2), 519-529. PubMed doi:10.1007/s00726-011-1132-7

Halliday, T.M., Peterson, N.J., Thomas, J.J., Kleppinger, K., Hollis, B.W., \& Larson-Meyer, D.E. (2011). Vitamin D status relative to diet, lifestyle, injury, and illness in college athletes. Medicine \& Science in Sports \& Exercise, 43(2), 335-343. PubMed doi:10.1249/MSS. 0b013e3181eb9d4d

Hamilton, B., Grantham, J., Racinais, S., \& Chalabi, H. (2010). Vitamin D deficiency is endemic in Middle Eastern sportsmen. Public Health Nutrition, 13(10), 1528-1534. PubMed doi:10.1017/S136898000 999320X

Harris, R.C., Söderlund, K., \& Hultman, E. (1992). Elevation of creatine in resting and exercised muscle of normal subjects by creatine supplementation. Clinical Science (London, England: 1979), 83(3), 367-374. doi:10.1042/cs0830367

Häussinger, D., Roth, E., Lang, F., \& Gerok, W. (1993). Cellular hydration state: An important determinant of protein catabolism in health and disease. Lancet, 341(8856), 1330-1332. doi:10.1016/0140-6736(93) 90828-5

Haywood, B.A., Black, K.E., Baker, D., McGarvey, J., Healey, P., \& Brown, R.C. (2014). Probiotic supplementation reduces the duration and incidence of infections but not severity in elite rugby union players. Journal of Science and Medicine in Sport, 17(4), 356-360. PubMed doi:10.1016/j.jsams.2013.08.004

He, C.S., Aw Yong, X.H., Walsh, N.P., \& Gleeson, M. (2016). Is there an optimal vitamin D status for immunity in athletes and military personnel? Exercise Immunology Review, 22, 42-64. PubMed

He, C.S., Fraser, W.D., Tang, J., Brown, K., Renwick, S., RudlandThomas, J., . . . Gleeson, M. (2016). The effect of 14 weeks of vitamin D3 supplementation on antimicrobial peptides and proteins in athletes. Journal of Sports Sciences, 34(1), 67-74. PubMed doi:10.1080/02640414.2015.1033642

He, C.S., Handzlik, M., Fraser, W.D., Muhamad, A., Preston, H., Richardson, A., \& Gleeson, M. (2013). Influence of vitamin D status on respiratory infection incidence and immune function during 4 months of winter training in endurance sport athletes. Exercise Immunology Review, 19, 86-101. PubMed

Heaton, L.E., Davis, J.K., Rawson, E.S., Nuccio, R.P., Witard, O.C., Stein, K.W., . . Baker, L.B. (2017). Selected in season nutritional strategies to enhance recovery for team sport athletes. Sports Medicine, 47(11), 2201-2218.

Hector, A., \& Phillips, S.M. (2018). Protein recommendations for weight loss in elite athletes: A focus on body composition and performance. International Journal of Sport Nutrition and Exercise Metabolism, 28. doi:10.1123/ijsnem.2017-0273

Hespel, P., Op't Eijnde, B., Van Leemputte, M., Urso, B., Greenhaff, P.L., Labarque, V., . . . Richter, E.A. (2001). Oral creatine supplementation facilitates the rehabilitation of disuse atrophy and alters the expression of muscle myogenic factors in humans. Journal of Physiology, 536(Pt 2), 625-633. PubMed doi:10.1111/j.1469-7793.2001.0625c.xd

Holick, M.F., Binkley, N.C., Bischoff-Ferrari, H.A., Gordon, C.M., Hanley, D.A., Heaney, R.P., . . Endocrine, S. (2011). Evaluation, treatment, and prevention of vitamin D deficiency: An Endocrine Society clinical practice guideline. Journal of Clinical Endocrinology and Metabolism, 96(7), 1911-1930. PubMed doi:10.1210/jc.20110385

Hossein-nezhad, A., \& Holick, M.F. (2013). Vitamin D for health: A global perspective. Mayo Clinic Proceedings, 88(7), 720-755. doi:10.1016/j.mayocp.2013.05.011

Hultman, E., Söderlund, K., Timmons, J.A., Cederblad, G., \& Greenhaff, P.L. (1996). Muscle creatine loading in men. J Appl Physiol (1985), 81(1), 232-237. doi:10.1152/jappl.1996.81.1.232

Jeromson, S., Gallagher, I.J., Galloway, S.D., \& Hamilton, D.L. (2015). Omega-3 fatty acids and skeletal muscle health. Marine Drugs, 13(11), 6977-7004. PubMed doi:10.3390/md13116977

Johnston, A.P., Burke, D.G., MacNeil, L.G., \& Candow, D.G. (2009). Effect of creatine supplementation during cast-induced immobilization on the preservation of muscle mass, strength, and endurance. Journal of Strength \& Conditioning Research, 23(1), 116-120. PubMed doi:10.1519/JSC.0b013e31818efbcc

Jouris, K.B., McDaniel, J.L., \& Weiss, E.P. (2011). The effect of omega-3 fatty acid supplementation on the inflammatory response to eccentric strength exercise. Journal of Sports Science \& Medicine, 10(3), 432-438. PubMed

Kekkonen, R.A., Vasankari, T.J., Vuorimaa, T., Haahtela, T., Julkunen, I., \& Korpela, R. (2007). The effect of probiotics on respiratory infections and gastrointestinal symptoms during training in marathon runners. International Journal of Sport Nutrition and Exercise Metabolism, 17(4), 352-363. PubMed doi:10.1123/ijsnem.17.4.352 
Laaksi, I., Ruohola, J.P., Tuohimaa, P., Auvinen, A., Haataja, R., Pihlajamaki, H., \& Ylikomi, T. (2007). An association of serum vitamin $\mathrm{D}$ concentrations $<40 \mathrm{nmol} / \mathrm{L}$ with acute respiratory tract infection in young Finnish men. American Journal of Clinical Nutrition, 86(3), 714-717. PubMed

Lamprecht, M., Bogner, S., Schippinger, G., Steinbauer, K., Fankhauser, F., Hallstroem, S., . . G Greilberger, J.F. (2012). Probiotic supplementation affects markers of intestinal barrier, oxidation, and inflammation in trained men; a randomized, double-blinded, placebo-controlled trial. Journal of the International Society of Sports Nutrition, 9(1), 45. PubMed doi:10.1186/1550-2783-9-45

Lancaster, G.I., Halson, S.L., Khan, Q., Drysdale, P., Wallace, F., Jeukendrup, A.E., . . . Gleeson, M. (2004). Effects of acute exhaustive exercise and chronic exercise training on type 1 and type 2 T lymphocytes. Exercise Immunology Review, 10, 91-106. PubMed

Lappe, J., Cullen, D., Haynatzki, G., Recker, R., Ahlf, R., \& Thompson, K. (2008). Calcium and vitamin D supplementation decreases incidence of stress fractures in female navy recruits. Journal of Bone and Mineral Research, 23(5), 741-749. PubMed doi:10.1359/jbmr. 080102

Larson-Meyer, D.E. (2015). The importance of vitamin D for athletes. GSSE, 28(148), 1-6.

Larson-Meyer, D.E., Woolf, K., \& Burke, L.M. (2018). Assessment of nutrient status in athletes and the need for supplementation. International Journal of Sports Nutrition and Exercise Metabolism, 28. doi:10.1123/ijsnem.2017-0338

Lewis, M., Ghassemi, P., \& Hibbeln, J. (2013). Therapeutic use of omega3 fatty acids in severe head trauma. American Journal of Emergency Medicine, 31(1), 273.e5-273.e8. PubMed doi:10.1016/j.ajem.2012. 05.014

Louis, M., Poortmans, J.R., Francaux, M., Berre, J., Boisseau, N., Brassine, E., . . Rennie, M.J. (2003). No effect of creatine supplementation on human myofibrillar and sarcoplasmic protein synthesis after resistance exercise. American Journal of Physiology: Endocrinology and Metabolism, 285(5), E1089-E1094. PubMed doi:10. 1152/ajpendo.00195.2003

Louis, M., Poortmans, J.R., Francaux, M., Hultman, E., Berre, J., Boisseau, N., . . Rennie, M.J. (2003). Creatine supplementation has no effect on human muscle protein turnover at rest in the postabsorptive or fed states. American Journal of Physiology: Endocrinology and Metabolism, 284(4), E764-E770. PubMed

Lowery, R.P., Joy, J.M., Rathmacher, J.A., Baier, S.M., Fuller, J.C., Jr., Shelley, M.C., 2nd, . . . Wilson, J.M. (2016). Interaction of betahydroxy-beta-methylbutyrate free acid and adenosine triphosphate on muscle mass, strength, and power in resistance trained individuals. Journal of Strength \& Conditioning Research, 30(7), 1843-1854. PubMed doi:10.1519/JSC.0000000000000482

MacDougall, J.D., Ward, G.R., Sale, D.G., \& Sutton, J.R. (1977). Biochemical adaptation of human skeletal muscle to heavy resistance training and immobilization. Journal of Applied Physiology, 43(4), 700-703.

Maroon, J.C., Mathyssek, C.M., Bost, J.W., Amos, A., Winkelman, R., Yates, A.P., . . Norwig, J.A. (2015). Vitamin D profile in National Football League players. American Journal of Sports Medicine, 43(5), 1241-1245. doi:10.1177/0363546514567297

Martin, S.A., Pence, B.D., \& Woods, J.A. (2009). Exercise and respiratory tract viral infections. Exercise and Sport Sciences Reviews, 37(4), 157-164. PubMed doi:10.1097/JES.0b013e3181b7b57b

McAlindon, T.E., Nuite, M., Krishnan, N., Ruthazer, R., Price, L.L., Burstein, D., . . . Flechsenhar, K. (2011). Change in knee osteoarthritis cartilage detected by delayed gadolinium enhanced magnetic resonance imaging following treatment with collagen hydrolysate: A pilot randomized controlled trial. Osteoarthritis and Cartilage, 19(4), 399-405. PubMed doi:10.1016/j.joca.2011.01.001

McFarlin, B.K., Venable, A.S., Henning, A.L., Sampson, J.N., Pennel, K., Vingren, J.L., \& Hill, D.W. (2016). Reduced inflammatory and muscle damage biomarkers following oral supplementation with bioavailable curcumin. BBA Clinical, 5, 72-78. PubMed doi:10. 1016/j.bbacli.2016.02.003

McGlory, C., Wardle, S.L., Macnaughton, L.S., Witard, O.C., Scott, F., Dick, J., . . . Tipton, K.D. (2016). Fish oil supplementation suppresses resistance exercise and feeding-induced increases in anabolic signaling without affecting myofibrillar protein synthesis in young men. Physiological Reports, 4(6), e12715. doi:10.14814/phy2.12715

Michalickova, D., Minic, R., Dikic, N., Andjelkovic, M., KosticVucicevic, M., Stojmenovic, T., . . . Djordjevic, B. (2016). Lactobacillus helveticus Lafti L10 supplementation reduces respiratory infection duration in a cohort of elite athletes: A randomized, doubleblind, placebo-controlled trial. Applied Physiology, Nutrition, and Metabolism, 41(7), 782-789. doi:10.1139/apnm-2015-0541

Mickleborough, T.D. (2013). Omega-3 polyunsaturated fatty acids in physical performance optimization. International Journal of Sport Nutrition and Exercise Metabolism, 23(1), 83-96. doi:10.1123/ ijsnem.23.1.83

Molfino, A., Gioia, G., Rossi Fanelli, F., \& Muscaritoli, M. (2013). Betahydroxy-beta-methylbutyrate supplementation in health and disease: A systematic review of randomized trials. Amino Acids, 45(6), 12731292.

Morton, J.P., Iqbal, Z., Drust, B., Burgess, D., Close, G.L., \& Brukner, P.D. (2012). Seasonal variation in vitamin D status in professional soccer players of the English Premier League. Applied Physiology, Nutrition, and Metabolism, 37(4), 798-802. PubMed doi:10.1139/ h2012-037

Nelson, A.G., Arnall, D.A., Kokkonen, J., Day, R., \& Evans, J. (2001). Muscle glycogen supercompensation is enhanced by prior creatine supplementation. Medicine \& Science in Sports \& Exercise, 33(7), 1096-1100. PubMed doi:10.1097/00005768-200107000-00005

Nicol, L.M., Rowlands, D.S., Fazakerly, R., \& Kellett, J. (2015). Curcumin supplementation likely attenuates delayed onset muscle soreness (DOMS). European Journal of Applied Physiology, 115(8), 1769-1777. PubMed doi:10.1007/s00421-015-3152-6

Nissen, S., \& Sharp, R. (2003). Effect of dietary supplements on lean mass and strength gains with resistance exercise: A meta-analysis. Journal of Applied Physiology, 94(2), 651-659.

Nissen, S., Sharp, R., Ray, M., Rathmacher, J.A., Rice, D., Fuller, J.C. Jr., . . . Abumrad, N. (1996). Effect of leucine metabolite beta-hydroxybeta-methylbutyrate on muscle metabolism during resistance-exercise training. Journal of Applied Physiology, 81(5), 2095-2104.

Olsen, S., Aagaard, P., Kadi, F., Tufekovic, G., Verney, J., Olesen, J.L., . . . Kjaer, M. (2006). Creatine supplementation augments the increase in satellite cell and myonuclei number in human skeletal muscle induced by strength training. Journal of Physiology, 573(Pt 2), 525-534. PubMed doi:10.1113/jphysiol.2006.107359

Op 't Eijnde, B., Urso, B., Richter, E.A., Greenhaff, P.L., \& Hespel, P. (2001). Effect of oral creatine supplementation on human muscle GLUT4 protein content after immobilization. Diabetes, 50(1), 18-23. doi: $10.2337 /$ diabetes.50.1.18

Owens, D.J., Sharples, A.P., Polydorou, I., Alwan, N., Donovan, T., Tang, J., . . Close, G.L. (2015). A systems-based investigation into vitamin D and skeletal muscle repair, regeneration, and hypertrophy. American Journal of Physiology: Endocrinology and Metabolism, 309(12), E1019-E1031. PubMed doi:10.1152/ajpendo.00375. 2015 
Owens, D.J., Tang, J.C., Bradley, W.J., Sparks, A.S., Fraser, W.D., Morton, J.P., \& Close, G.L. (2017). Efficacy of high-dose vitamin D supplements for elite athletes. Medicine \& Science in Sports \& Exercise, 49(2), 349-356. doi:10.1249/MSS.0000000000001105

Owens, D.J., Webber, D., Impey, S.G., Tang, J., Donovan, T.F., Fraser, W.D., . . Close, G.L. (2014). Vitamin D supplementation does not improve human skeletal muscle contractile properties in insufficient young males. European Journal of Applied Physiology, 114(6), 1309-1320. doi:10.1007/s00421-014-2865-2

Parise, G., Mihic, S., MacLennan, D., Yarasheski, K.E., \& Tarnopolsky, M.A. (2001). Effects of acute creatine monohydrate supplementation on leucine kinetics and mixed-muscle protein synthesis. Journal of Applied Physiology, 91(3), 1041-1047. doi:10.1152/jappl.2001.91. 3.1041

Peeling, P., Binnie, M.J., Goods, P.S.R., Sim, M., \& Burke, L.M. (2018). Evidence-based supplements for the enhancement of athletic performance. International Journal of Sport Nutrition and Exercise Metabolism, 28. doi:10.1123/ijsnem.2017-0343

Phillips, S.M., Aragon, A.A., Arciero, P.J., Arent, S.M., Close, G.L., Hamilton, D.L., . . . Willoughby, D.S. (2017). Changes in body composition and performance with supplemental HMB-FA+ATP. Journal of Strength \& Conditioning Research, 31(5), e71-e72. doi:10.1519/JSC.0000000000001760

Pyne, D.B., West, N.P., Cox, A.J., \& Cripps, A.W. (2015). Probiotics supplementation for athletes - clinical and physiological effects. European Journal of Sport Science, 15(1), 63-72. doi:10.1080/ 17461391.2014 .971879

Rae, C.D., \& Broer, S. (2015). Creatine as a booster for human brain function. How might it work? Neurochemistry International, 89, 249-259. doi:10.1016/j.neuint.2015.08.010

Rawson, E.S., Clarkson, P.M., \& Tarnopolsky, M.A. (2017). Perspectives on exertional rhabdomyolysis. Sports Medicine, 47(Suppl 1), 33-49. PubMed doi:10.1007/s40279-017-0689-z

Rawson, E.S., \& Venezia, A.C. (2011). Use of creatine in the elderly and evidence for effects on cognitive function in young and old. Amino Acids, 40(5), 1349-1362. PubMed doi:10.1007/s00726-011-0855-9

Rawson, E.S., \& Volek, J.S. (2003). Effects of creatine supplementation and resistance training on muscle strength and weightlifting performance. Journal of Strength \& Conditioning Research, 17(4), 822-831. PubMed

Roberts, P.A., Fox, J., Peirce, N., Jones, S.W., Casey, A., \& Greenhaff, P.L. (2016). Creatine ingestion augments dietary carbohydrate mediated muscle glycogen supercompensation during the initial $24 \mathrm{~h}$ of recovery following prolonged exhaustive exercise in humans. Amino Acids, 48(8), 1831-1842. PubMed doi:10.1007/s00726-016-2252-x

Rowlands, D.S., \& Thomson, J.S. (2009). Effects of beta-hydroxybeta-methylbutyrate supplementation during resistance training on strength, body composition, and muscle damage in trained and untrained young men: A meta-analysis. Journal of Strength \& Conditioning Research, 23(3), 836-846. PubMed doi:10.1519/JSC. 0b013e3181a00c80

Ruohola, J.P., Laaksi, I., Ylikomi, T., Haataja, R., Mattila, V.M., Sahi, T., . . Pihlajamaki, H. (2006). Association between serum 25(OH)D concentrations and bone stress fractures in Finnish young men. Journal of Bone and Mineral Research, 21(9), 1483-1488. PubMed doi:10.1359/jbmr.060607

Sabetta, J.R., DePetrillo, P., Cipriani, R.J., Smardin, J., Burns, L.A., \& Landry, M.L. (2010). Serum 25-hydroxyvitamin d and the incidence of acute viral respiratory tract infections in healthy adults. PLOS ONE, 5(6), e11088. PubMed doi:10.1371/journal.pone.0011088

Safdar, A., Yardley, N.J., Snow, R., Melov, S., \& Tarnopolsky, M.A. (2008). Global and targeted gene expression and protein content in skeletal muscle of young men following short-term creatine monohydrate supplementation. Physiological Genomics, 32(2), 219-228. PubMed doi:10.1152/physiolgenomics.00157.2007

Sakellaris, G., Kotsiou, M., Tamiolaki, M., Kalostos, G., Tsapaki, E., Spanaki, M., . . Evangeliou, A. (2006). Prevention of complications related to traumatic brain injury in children and adolescents with creatine administration: An open label randomized pilot study. Journal of Trauma, 61(2), 322-329. doi:10.1097/01.ta.0000230269. 46108.d5

Sakellaris, G., Nasis, G., Kotsiou, M., Tamiolaki, M., Charissis, G., \& Evangeliou, A. (2008). Prevention of traumatic headache, dizziness and fatigue with creatine administration. A pilot study. Acta Paediatrica, 97(1), 31-34. PubMed doi:10.1111/j.1651-2227.2007. 00529. $\mathrm{x}$

Sanchez-Martinez, J., Santos-Lozano, A., Garcia-Hermoso, A., Sadarangani, K.P., \& Cristi-Montero, C. (2017). Effects of beta-hydroxy-betamethylbutyrate supplementation on strength and body composition in trained and competitive athletes: A meta-analysis of randomized controlled trials. Journal of Science and Medicine in Sport. doi:10. 1016/j.jsams.2017.11.003

Sciberras, J.N., Galloway, S.D., Fenech, A., Grech, G., Farrugia, C., Duca, D., \& Mifsud, J. (2015). The effect of turmeric (Curcumin) supplementation on cytokine and inflammatory marker responses following 2 hours of endurance cycling. Journal of the International Society of Sports Nutrition, 12(1), 5. PubMed doi:10.1186/s12970014-0066-3

Shaw, G., Lee-Barthel, A., Ross, M.L., Wang, B., \& Baar, K. (2017). Vitamin C-enriched gelatin supplementation before intermittent activity augments collagen synthesis. American Journal of Clinical Nutrition, 105(1), 136-143. PubMed doi:10.3945/ajen.116.138594

Shing, C.M., Peake, J.M., Lim, C.L., Briskey, D., Walsh, N.P., Fortes, M.B., . . Vitetta, L. (2014). Effects of probiotics supplementation on gastrointestinal permeability, inflammation and exercise performance in the heat. European Journal of Applied Physiology, 114(1), 93-103. PubMed doi:10.1007/s00421-013-2748-y

Smith, G.I., Atherton, P., Reeds, D.N., Mohammed, B.S., Rankin, D., Rennie, M.J., \& Mittendorfer, B. (2011a). Dietary omega-3 fatty acid supplementation increases the rate of muscle protein synthesis in older adults: A randomized controlled trial. American Journal of Clinical Nutrition, 93(2), 402-412. PubMed doi:10.3945/ajcn.110. 005611

Smith, G.I., Atherton, P., Reeds, D.N., Mohammed, B.S., Rankin, D., Rennie, M.J., \& Mittendorfer, B. (2011b). Omega-3 polyunsaturated fatty acids augment the muscle protein anabolic response to hyperinsulinaemia-hyperaminoacidaemia in healthy young and middleaged men and women. Clinical Science (London, England: 1979), 121(6), 267-278. PubMed doi:10.1042/CS20100597

Strasser, B., Geiger, D., Schauer, M., Gostner, J.M., Gatterer, H., Burtscher, M., \& Fuchs, D. (2016). Probiotic supplements beneficially affect tryptophan-kynurenine metabolism and reduce the incidence of upper respiratory tract infections in trained athletes: A randomized, double-blinded, placebo-controlled trial. Nutrients, 8(11), 752. PubMed doi:10.3390/nu8110752

Sullivan, P.G., Geiger, J.D., Mattson, M.P., \& Scheff, S.W. (2000). Dietary supplement creatine protects against traumatic brain injury. Annals of Neurology, 48(5), 723-729. PubMed doi:10.1002/15318249(200011)48:5<723::AID-ANA5>3.0.CO;2-W

Szczesniak, K.A., Ostaszewski, P., Fuller, J.C., Jr., Ciecierska, A., \& Sadkowski, T. (2015). Dietary supplementation of beta-hydroxybeta-methylbutyrate in animals-a review. Journal of Animal Physiology and Animal Nutrition, 99(3), 405-417. PubMed doi:10. 1111/jpn.12234 
Tipton, K.D. (2015). Nutritional support for exercise-induced injuries. Sports Medicine, 45(Suppl 1), 93-104. doi:10.1007/s40279-015-0398-4

Turner, C.E., Byblow, W.D., \& Gant, N. (2015). Creatine supplementation enhances corticomotor excitability and cognitive performance during oxygen deprivation. Journal of Neuroscience, 35(4), 1773-1780. PubMed doi:10.1523/JNEUROSCI.3113-14.2015

Vagnozzi, R., Signoretti, S., Floris, R., Marziali, S., Manara, M., Amorini, A.M., ... Tavazzi, B. (2013). Decrease in N-acetylaspartate following concussion may be coupled to decrease in creatine. Journal of Head Trauma Rehabilitation, 28(4), 284-292. PubMed doi:10.1097/HTR. 0b013e3182795045

Volek, J.S., \& Rawson, E.S. (2004). Scientific basis and practical aspects of creatine supplementation for athletes. Nutrition, 20(7-8), 609-614. doi:10.1016/j.nut.2004.04.014

West, N.P., Pyne, D.B., Cripps, A.W., Hopkins, W.G., Eskesen, D.C., Jairath, A., . . Fricker, P.A. (2011). Lactobacillus fermentum (PCC (R)) supplementation and gastrointestinal and respiratory-tract illness symptoms: A randomised control trial in athletes. Nutrition Journal, 10, 30. PubMed doi:10.1186/1475-2891-10-30

West, N.P., Pyne, D.B., Peake, J.M., \& Cripps, A.W. (2009). Probiotics, immunity and exercise: A review. Exercise Immunology Review, 15, 107-126. PubMed

Wilkinson, D.J., Hossain, T., Hill, D.S., Phillips, B.E., Crossland, H., Williams, J., . . . Atherton, P.J. (2013). Effects of leucine and its metabolite beta-hydroxy-beta-methylbutyrate on human skeletal muscle protein metabolism. Journal of Physiology, 591(11), 2911-2923. PubMed doi:10.1113/jphysiol.2013.253203

Willoughby, D.S., \& Rosene, J. (2001). Effects of oral creatine and resistance training on myosin heavy chain expression. Medicine \& Science in Sports \& Exercise, 33(10), 1674-1681. PubMed doi:10. 1097/00005768-200110000-00010
Willoughby, D.S., \& Rosene, J.M. (2003). Effects of oral creatine and resistance training on myogenic regulatory factor expression. Medicine \& Science in Sports \& Exercise, 35(6), 923-929. doi:10. 1249/01.MSS.0000069746.05241.F0

Wilson, J.M., Lowery, R.P., Joy, J.M., Andersen, J.C., Wilson, S.M., Stout, J.R., . . Rathmacher, J. (2014). The effects of 12 weeks of beta-hydroxy-beta-methylbutyrate free acid supplementation on muscle mass, strength, and power in resistance-trained individuals: A randomized, double-blind, placebo-controlled study. European Journal of Applied Physiology, 114(6), 1217-1227. doi:10.1007/ s00421-014-2854-5

Wilson, J.M., Lowery, R.P., Joy, J.M., Walters, J.A., Baier, S.M., Fuller, J.C., Jr., . . . Rathmacher, J. (2013). Beta-hydroxy-betamethylbutyrate free acid reduces markers of exercise-induced muscle damage and improves recovery in resistance-trained men. British Journal of Nutrition, 110(3), 538-544. doi:10.1017/S0007114512 005387

Wu, H., Xia, Y., Jiang, J., Du, H., Guo, X., Liu, X., . . Niu, K. (2015). Effect of beta-hydroxy-beta-methylbutyrate supplementation on muscle loss in older adults: A systematic review and meta-analysis. Archives of Gerontology and Geriatrics, 61(2), 168-175. PubMed doi:10.1016/j.archger.2015.06.020

Yquel, R.J., Arsac, L.M., Thiaudiere, E., Canioni, P., \& Manier, G. (2002). Effect of creatine supplementation on phosphocreatine resynthesis, inorganic phosphate accumulation and $\mathrm{pH}$ during intermittent maximal exercise. Journal of Sports Sciences, 20(5), 427-437. PubMed doi:10.1080/026404102317366681

Zanchi, N.E., Gerlinger-Romero, F., Guimaraes-Ferreira, L., de Siqueira Filho, M.A., Felitti, V., Lira, F.S., . . Lancha, A.H. Jr. (2011). HMB supplementation: Clinical and athletic performance-related effects and mechanisms of action. Amino Acids, 40(4), 1015-1025. 